УДК 005.332.4:338.48

\title{
УПРАВЛІННЯ КОНКУРЕНТОСПРОМОЖНІСТЮ ТУРИСТИЧНОГО ПІДПРИЕМСТВА В УМОВАХ НЕСТАБІЛЬНОСТІ
}

\section{MANAGEMENT OF COMPETITIVENESS OF THE TOURIST ENTERPRISE IN INSTABILITY CONDITIONS}

\author{
Кравченко Оксана Михайлівна \\ кандидат економічних наук, \\ Національний університет «Одеська політехніка» \\ ORCID: https://orcid.org/0000-0002-3389-3218 \\ Лапіна Ірина Сергіївна \\ кандидат економічних наук, доцент, \\ Одеський національний економічний університет \\ ORCID: https://orcid.org/0000-0002-1946-1873 \\ Бєлобров Олександр Дмитрович \\ студент, \\ Національний університет «Одеська політехніка» \\ ORCID: https://orcid.org/0000-0002-8632-3251
}

\author{
Kravchenko Oksana \\ Odessa Polytechnic National University \\ Lapina Iryna \\ Odessa National University of Economics \\ Bielobrov Oleksandr \\ Odessa Polytechnic National University
}

\begin{abstract}
Стаття присвячена питанням управління конкурентоспроможністю туристичного підприємства в умовах нестабільності. В статті проаналізовано основні тенденції, що склались на ринку туристичних послуг України і світу, вплив пандемії на формування туристичних потоків, обсяг ринку туристичних послуг, та транссормація вимог до конкурентоспроможності туристичних підприємств. Було виділено фактори, що впливають на рівень конкурентоспроможності підприємств ринку туристичних послуг України, що були розподілені за чотирма ієрархічними рівнями: мега-, макро-, мезо-, та мікро- рівнями. За результатами проведеного дослідження було представлено власне бачення процесу управління конкурентоспроможністю туристичного підприємства в умовах нестабільності. Особливу увагу було приділено необхідності здійснення перманентного моніторингу змін у зовнішньому середовищі, та оперативного реагування на них, що має знаходити відображення в процесі управління, фрормуючи гнучку систему швидкого реагування.
\end{abstract}

Ключові слова: конкурентоспроможність, конкурентоспроможність туристичного підприємства, управління конкурентоспроможністю, фрактори конкурентоспроможності, конкурентоспроможність в умовах нестабільності.

Статья посвящена вопросам управления конкурентоспособностью туристического компании в условиях нестабильности. В статье проанализированы основные тенденции, сложившиеся на рынке туристических услуг Украины и мира, влияние пандемии на формирование туристических потоков, объем рынка туристических услуг и трансорормация требований к конкурентоспособности туристических предприятий. Были выделены фракторы, влияющие на уровень конкурентоспособности предприятий рынка туристических услуг Украины. Они были распределены по четырем иерархическим уровням: мега-, макро-, мезо-, и микроуровням. В результате проведенного исследования было представлено собственное видение процесса управления конкурентоспособностью туристического предприятия в условиях нестабильности. Особое внимание было уделено необходимости осуществления перманентного мониторинга изменений во внешней среде и опе- 
ративного реагирования на них, что должно находить отражение в процессе управления, фрормируя гибкую систему быстрого реагирования.

Ключевые слова: конкурентоспособность, конкурентоспособность туристического предприятия, управление конкурентоспособностью, фракторы конкурентоспособности, конкурентоспособность в условиях нестабильности.

The purpose of the article is to substantiate the theoretical and methodological principles, study the state, trends and factors of competitiveness of the tourist enterprise, and provide recommendations for building a system for managing the competitiveness of the tourist enterprise. Competitiveness management is a task that should be faced by the leadership of any organization operating in today's fierce competition. The tourism industry in Ukraine and the world is developing rapidly, the number of tourism enterprises is quite large, and they all claim their own market share, popularity among customers, and hope for high efficiency. The pandemic has also changed the market, forcing many tourism businesses to close. The most resilient and competitive survived, which showed the vulnerability of those businesses that did not have a well-established system of governance, and existed only due to ever-increasing demand. Practice has shown that in crisis conditions, only those organizations survived that had a constant customer base and a well-coordinated management system. Despite the recent surge in activity in the tourism market due to accumulated deferred demand, the issue of competitiveness of tourism enterprises remains relevant, because they face a difficult task, retaining customers and forming a competitive tourism product in conditions of instability and ever-changing constraints. high risks of long-term planning, falling level of consumer solvency. To solve the tasks set in the work, the method of theoretical and empirical research was used, which includes analysis and synthesis, comparison and generalization. The article analyzes the main trends in the market of tourist services of Ukraine and the world, the impact of the pandemic on the formation of tourist flows, the volume of the market of tourist services, and the transformation of requirements for competitiveness of tourist enterprises. Factors influencing the level of competitiveness of enterprises in the market of tourist services of Ukraine were identified, which were divided into four hierarchical levels: mega-, macro-, meso-, and micro-levels. According to the results of the study, the vision of the process of managing the competitiveness of a tourist enterprise in conditions of instability was presented. Particular attention was paid to the need for permanent monitoring of changes in the external environment, and rapid response to them, which should be reflected in the management process, forming a flexible system of rapid response.

Keywords: competitiveness, competitiveness of a tourist enterprise, competitiveness management, factors of competitiveness, competitiveness in conditions of instability.

Постановка проблеми. В сучасних умовах нестабільності та невизначеності, що супроводжує діяльність туристичних підприємств з моменту появи перших ознак пандемії, питання конкурентоспроможності стають особливо гостро. Постійні зміни до вимог 3 перетину кордонів, посилення та послаблення карантинних вимог в усьому світі, та періодичні введення повних локдаунів фрактично стагнували галузь, та навіть призвели до значного ії̈ скорочення. В таких умовах, багато підприємств туристичної галузі змушені були піти з ринку, а ті що залишились знаходяться у стані виживання та жорсткої конкуренції за попит, що значно скоротився. За прогнозами Всесвітньої туристичної організації, відновлення рівня туристичного потоку допандемічного періоду очікується не раніше 2024 року. В таких умовах, управління конкурентоспроможністю туристичного підприємства стає однією 3 найголовніших задач менеджменту, адже тільки збереження попиту на продукцію підприємства може забезпечити йому сталі грошові надходження, що дають можливість зберегти робочі місця та акумулювати ресурси для подальшого розвитку організації.
Аналіз останніх досліджень та публікацій. Питанням управління конкурентоспроможністю взагалі, та конкурентоспроможністю туристичних підприємств зокрема, присвячено труди багатьох дослідників: Кадирус І.Г., Підлужна О.Б., Колос 3.В., Мануйлович Ю.М., Лужанська Т.Ю., Костенко С.А., Катц Е.Б., Будкевич Г.Б., Солов'янчик А.В., Кравченко О.М., Кула М.В., Левицький Д.В., Яценко М.С., Беспала О.А., Ференець Я.В., Храпкіна В.В., Солов'янчик А.В., Гавриш О.А., Діденко О.Є., Жураківський П.І., Драган О.І. [1-6; 11-16].

Формування цілей статті. Мета статті полягає в тому, щоб проаналізувати існуючий теоретичний базис стосовно питань управління конкурентоспроможністю туристичного підприємства, виявити найновіші тенденції стану та розвитку туристичної індустрії в Україні і світі, фрактори впливу на конкурентоспроможність туристичних підприємств України, надати власне бачення процесу управління конкурентоспроможністю туристичного підприємства в умовах нестабільності.

Виклад основного матеріалу. В сучасній літературі поняття конкурентоспроможності взагалі, та конкурентоспроможності туристичного підприємства зокрема, розглядається 
різними авторами [1-6], кожен з яких надає її власне визначення, акцентуючи увагу на тих чи інших її складових.

Конкурентоспроможність туристичного підприємства це досить комплексне, системне поняття, що в сучасних умовах має базуватись водночас на принципах стійкості та гнучкості підприємства, при неодмінному збереженні ефрективності його фрункціонування, не допущення скорочення масштабів діяльності, закріпленні та розширенні позицій на ринку туристичних послуг.

До приходу пандемії в 2019 році, індустрія туризму характеризувалась швидким зростанням. 3 настанням епохи глобальних обмежень, темпи зростання туристичної галузі стали від'ємними, зупинка туризму за більшістю направлень стала шоком як для операторів і агентів ринку, так і для підприємств розміщення, харчування, транспортування. Криза торкнулась всієї сфери обслуговування. На сьогоднішній день, ринок туризму характеризується пожвавленням. Має місце есрект так званого відкладеного попиту. Проте, навіть, не зважаючи на те, що ситуація в сорері туризму покращилась, все ще існує цілий ряд обмежень, що не дозволяють їй відновитись у повному обсязі. Водночас, по всьому світі зараз ідуть тенденції до впровадження усвідомленого споживання, що означає також тенденції до свідомого скорочення подорожей 3 метою збереження природних ресурсів. Туристичні підприємства знаходяться в атмоссрері постійних змін, що накладає певні вимоги на їх поведінку, побудову системи менеджменту, корегує їх цілі. 3 одного боку, галузь очистилась від слабких гравців ринку, з іншого боку, криза в туризмі продовжується, боротьба за платоспроможного споживача триває, в той час, як благополуччя населення падає по всьому світі. В таких умовах господарювання, навіть досить крупні гравці ринку відчувають себе вразливими, а конкуренція набуває якісно нового рівня, адже вижили сильніші.

ще одна тенденція, що на наш погляд спостерігається на ринку туристичних послуг, це підвищення вартості пропозицій. На наших очах закінчується епоха дешевих стокових турів. Не зважаючи на те, що попит поступово відновлюється, йому ще далеко до доковідних часів. По всьому світі дуже постраждала масовість туризму, яка забезпечувала можливість спускати ціну максимально низько. Поступово туризм повертається в більш дорогий сегмент дозвілля, і це фрормує замкнуте коло: подо- рожчання послуг сприяє зменшенню попитузменшення попиту сприяє подорожчанню послуг, через втрату масовості.

Все це ставить підприємства туристичної галузі в умови жорстокої конкуренції, коли стійкість та життєздатність стає характерною тільки для підприємств із злагодженою системою управління, що націлена на результат, а саме на забезпечення та створення потенціалу конкурентоспроможності.

Ринок туризму залишається нестабільним, та дуже залежним від зовнішніх обставин, пов'язаних з пандемією. Не дивлячись на короткострокові значні послаблення в обмеженнях, в споживачів все ще залишається страх їх раптового посилення, і цей страх $€$ виправданим. В таких умовах значно знижується частка раннього бронювання, що ставить усі об'єкти туристичної галузі в позицію невизначеності.

Згідно даних UNWTO (Всесвітньої туристичної організації), міжнародний туризм повернувся до рівня 30-ти річної давнини. Так, в 2020 році, міжнародний туризм скоротився на $74 \%$ (мається на увазі скорочення обсягів переміщення туристів приблизно на 1,1 мільярд), орієнтовна втрата надходжень від міжнародного туризму склала 1,3 трильйони дол. США, пов'язане з цим скорочення ВВП по всьому світу, близько 2 трильйонів дол. США.

Тенденцію зміни міжнародного туристичного потоку згідно даних UNWTO, в період 3 1990 р. по 2020 р., зображено на рис. 1. Дані подано 3 шагом в 5 років, проте, оскільки перехід між 2019 та 2020 роками був дуже показовим, для збільшення інформативності, було додано, також дані 2019 р.

Як ми бачимо, лише за один рік (проміжок 2019-2020рр.), обсяг туристичного потоку впав майже на 74\%, фрактично до рівня 30-ти річної давнини.

Для більш детального аналізу ситуації, що склалася, наведено також дані за 2020 р. помісячно, з додаванням даних за частину 2021 р. (рис. 2).

Грасрік на рис. 2 демонструє, що основний спад відбувся у січні-квітні 2020 р. Це було фрактично заморожування туризму по всьому світу, що призвело до колосальних збитків в учасників ринку, та закриття найбільш вразливих його учасників. Пікове скорочення прийшлося на квітень 2020 р., коли «лоқдауни» у всьому світі набули найбільш жорсткої фрорми. Потім спостерігається деяке пожвавлення ринку, та обсяги його зростання 


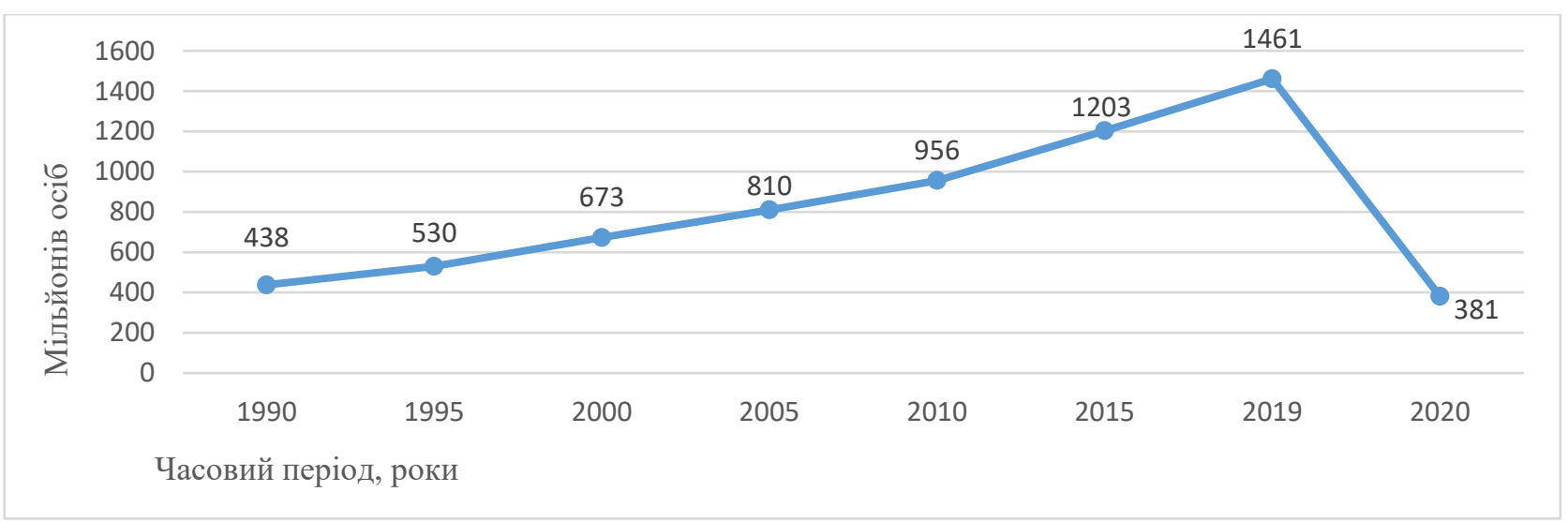

Рис. 1. Тенденція зміни міжнародного туристичного потоку згідно даних UNWTO, 1990-2020 pp.

Джерело: складено авторами за даними [7]

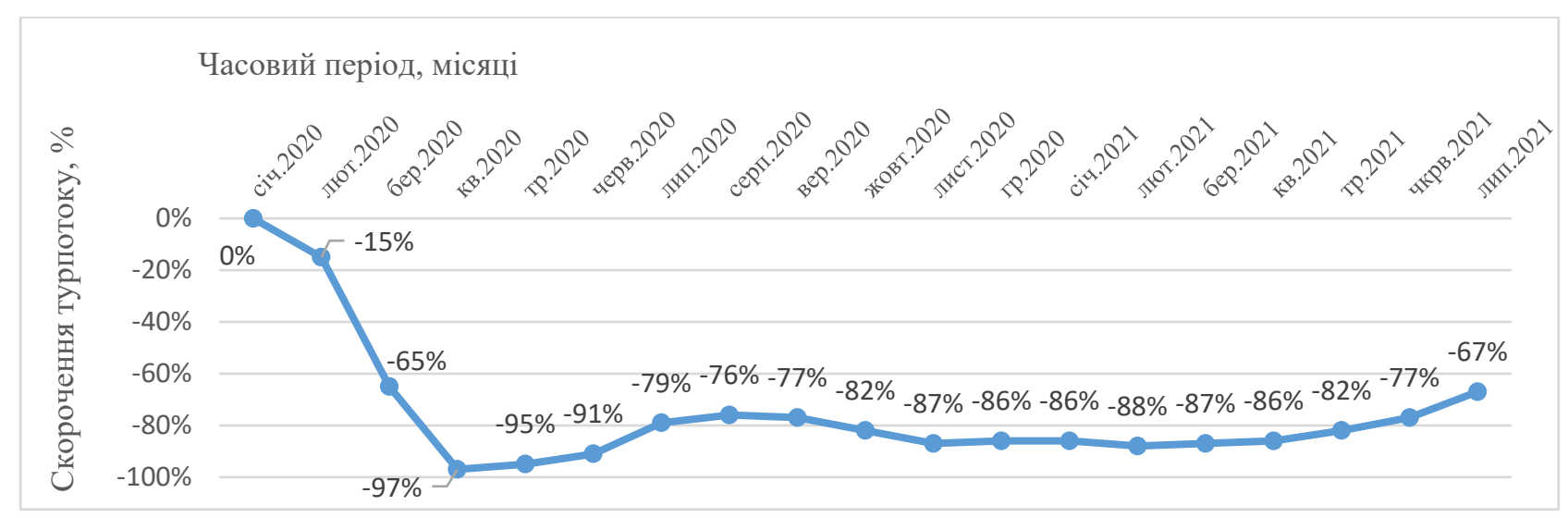

Рис. 2. Тенденція зміни міжнародного туристичного потоку згідно даних UNWTO в 2020-2021 рр., помісячно

Джерело: складено авторами за даними [7; 8]

настільки незначні, що ми не можемо казати про суттєві покращення у галузі. Рівень конкуренції між туристичними підприємствами, що залишились на ринку все ще висок. Сьогодні це фрактично війна за споживача.
В Україні падіння туристичного потоку теж відбулося, проте відносно загальносвітових тенденцій не настільки стрімке (рис. 3).

Як видно 3 рис. 3, в Україні темпи зростання туристичних потоків за останні десять

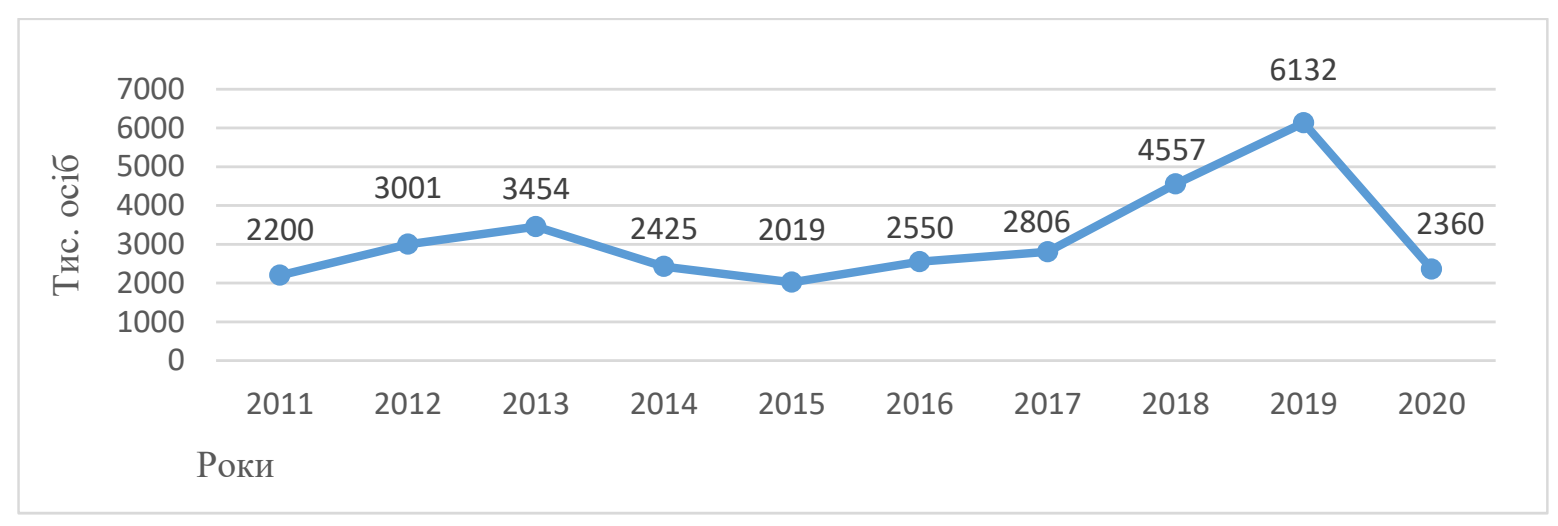

Рис. 3. Динаміка зміни туристичних потоків в Україні, 2011-2020 рр.

Джерело: складено авторами за даними [9; 10] 
років були менш жваві за загальносвітові. В період найгострішого прояву пандемії (2019-2020рр.), туристичний потік в Україні скоротився приблизно на $62 \%$, та сягнув рівня 2015-2017 рр. Отже, якщо в усьому світі, обсяги турпотоку скоротилися до рівня 30-ти річної давнини, то в Україні до рівня 3-річної давнини, що дає надію на менш болісне і більш швидке відновлення галузі.

В умовах невизначеності, нестабільності, що склалися, стає надзвичайно важливим проаналізувати усі зовнішні та внутрішні фактори, що впливають на конкурентоспроможність туристичного підприємства. Багато вчених приділяють увагу цьому питанню [1; 2; 5]. Одні 3 них досліджують фрактори, інші чинники, що впливають на конкурентоспроможність туристичних підприємств, проте по суті вони говорять одне й те саме.

За результатними проведеного аналізу існуючого теоретичного базису, нами було прийнято рішення згрупувати чинники, що впливають на рівень конкурентоспроможності підприємств ринку туристичних послуг України за чотирма рівнями: мегарівень (відображає загальносвітові тенденції та процеси), макрорівень (рівень держави); мезорівень (регіональний рівень), та мікрорівень (рівень підприємства), що відображено на рис. 4.

Безперечно, фрактори мегарівня здійснюють опосередкований вплив на рівень конкурентоспроможності підприємств ринку туристичних послуг в Україні. Так, зміни на мегарівні за окремими напрямами туризму можуть значно впливати на конкурентоспроможність та стійкість підприємств, що займаються туризмом саме в цих напрямах, та не подумали заздалегідь диверсифрікувати свої послуги за напрямами туризму.

Вплив фракторів макрорівня на рівень конкурентоспроможності підприємств ринку туристичних послуг в Україні $\epsilon$ більш прямим, адже усі суб'єкти господарювання України фрункціонують в єдиному правовому полі держави, та напряму залежать від політичних, економічних, соціальних процесів, що відбуваються у країні, а також екологічного стану, природоохоронних заходів, політики у сорері туризму.

Фактори макро- та мезорівнів можуть дещо збігатись, адже на території однієї країни багато процесів $є$ ідентичними в різних регіонах. В Україні на даний час не існує суттєвих відмінностей у законодавстві за регіонами, як ми можемо це спостерігати, наприклад, у Німеччині, де існує багато відмінностей в законодавстві окремих земель. Проте, певна ідентичність притаманна окремим регіонам $€$. Це пов'язано з різним рівнем економічного розвитку регіонів, що впливає на рівень життя населення в них, а отже і споживчі переваги та очікування щодо туризму, з різними природними умовами, що дозволяють окремим регіонам позиціонувати себе як туристичні, або промислові, та відповідно цього регіони можуть виступати генераторами туристичних послуг, або переважно споживачами туристичних послуг.

Щодо фракторів мікрорівня, то вони напряму впливають на конкурентоспроможність окремих підприємств туристичних послуг. Це ті фрактори, з якими безпосередньо працює керівництво фрірми, на які воно може впливати за допомогою грамотно сфрормованої системи управління, що і сама по собі виступає фрактором конкурентоспроможності, тобто одночасно може розглядатися 3 позиція як суб'єкта, так і об'єкта управління.

Задля забезпечення конкурентоспроможності підприємства на мікрорівні, одну 3 найважливіших ролей відіграє також побудова системи контролю якості продукції. Яценко М.С., Беспала О.А., та Ференець Я.Б. [11] наголошують на необхідності використання системи тотального менеджменту якості (TQM), як одного з сучасних методів контролю та оцінки якості на підприємстві, а також CALS-технології, та PDM-систем.

Від загальних тенденцій розвитку туристичного ринку в світі, та аналізу фракторів, що впливають на конкурентоспроможність туристичних підприємств України, перейдемо безпосередньо до питання управління конкурентоспроможністю туристичного підприємства.

Процес управління конкурентоспроможністю є об'єктом дослідження багато вчених [12-16].

Погоджуємося 3 Храпкіною В.В. [12], що досліджуючи сутність поняття управління конкурентоспроможністю підприємства, можна зазначити, що $є$ група науковців, які розглядають це поняття з точки зору фрункцій управління, менеджменту, інша - 3 точки зору сукупності певних дій та способів впливу, третя група як процес управління. Сучасна концепція управління конкурентоспроможністю підприємства має враховувати фрактори, які впливають на конкурентоспроможність підприємства. Вони можуть бути як внутрішніми, так і зовнішніми.

Зазначимо, що на нашу думку, якщо можливостей впливу на зовнішні фрактори для 


\begin{tabular}{|c|c|c|}
\hline \begin{tabular}{l}
\multicolumn{2}{c}{ Фактори мегарівня: } \\
- наявність \\
обмежень глобальних \\
пандемією; \\
- стан'язаних \\
транспортної інфраструктури, \\
та інтегрованість України у неї; \\
- наявність візових бар'єрів \\
та інших вимог до в’ізду- \\
виїзду, часу перебування; \\
- соціальна стабільність у \\
світі; \\
- природні явища (глобальна \\
зміна клімату, стихійні лиха та \\
ін.).
\end{tabular} & \multicolumn{2}{|c|}{$\begin{array}{l}\text { Факори макрорівня: } \\
\text { - адміністративно-регуляторні } \\
\text { регулювання сфери туризму, нормативно-правова } \\
\text { база, політика сприяння та ін.); } \\
\text { - стан та наявність військових конфліктів; } \\
\text { - міжнародне співробітництво (наявність в України } \\
\text { міжнародних домовленостей); } \\
\text { - соціально-економічні (рівень життя, кількість та } \\
\text { структура населення, соціальна стабільність в країні, } \\
\text { соціокультурні звички та ін.); } \\
\text { - інфраструктурні (розвиненість внутрішньої } \\
\text { транспортної інфраструктури, готельно-ресторанного } \\
\text { господарства, зв’язку, наявність та стан пам’яток); } \\
\text { - природні (наявність, стан, та доступність для } \\
\text { туристів природного багатства країни). }\end{array}$} \\
\hline \multicolumn{3}{|c|}{$\begin{array}{c}\text { Фактори, що впливають на рівень конкурентоспроможності підприємств } \\
\text { ринку туристичних послуг в Україні }\end{array}$} \\
\hline $\begin{array}{l}\text { Фактори мезорівня: } \\
\text { - соціально-економічна роз } \\
\text { регіону; } \\
\text { - розвиненість споріднених } \\
\text { галузей господарювання; } \\
\text { - наявність та рівень конкуре } \\
\text { - потенційні споживачі } \\
\text { вподобання; } \\
\text { - лояльність місцевої влади; } \\
\text { - наявність освітньої інфрас } \\
\text { що дозволяє здобути та п } \\
\text { кваліфікацію, обмінятися досві }\end{array}$ & $\begin{array}{l}\text { веність } \\
\text { визму } \\
\text { в; їх } \\
\text { ктури, } \\
\text { ищити } \\
\text {. }\end{array}$ & $\begin{array}{l}\text { Фактори мікрорівня: } \\
\text { - грамотно побудована гнучка система } \\
\text { управління; } \\
\text { - кваліфікований по перснал, } \\
\text { зацікавлений у результаті; } \\
\text { - конкурентоспроможний продукт; } \\
\text { - наявність ефективного маркетингу; } \\
\text { - продумані стандарти якості сервісу; } \\
\text { - сучасні програмні продукти, що } \\
\text { дозволяють впорядкувати процес } \\
\text { обслуговування; } \\
\text { - надійні партнери; } \\
\text { - репутація. }\end{array}$ \\
\hline
\end{tabular}

Рис. 4. Фактори, що впливають на рівень конкурентоспроможності підприємств ринку туристичних послуг в Україні

Джерело: власна розробка авторів на основі [1; 2; 5]

підприємств туристичної галузі практично не існує, то внутрішні фрактори мають виступати об'єктами управління конкурентоспроможністю, фактично виступаючи складовими конкурентоспроможності. Тобто, можемо сказати, що управління конкурентоспроможністю туристичного підприємства буде являти собою процес управління окремими внутрішніми складовими конкурентоспроможності. Таке управління повинно відбуватись з урахуванням зовнішніх фракторів конкурентоспро- можності, що є постійно змінними, особливо в сучасних умовах нестабільності, пов'язаних з викликами пандемії. Таким чином, можемо сказати, що процес управління в сучасних умовах повинен супроводжуватись постійним моніторингом зовнішнього середовища, та конкурентоспроможності послуг туристичного підприємства в нових умовах. Водночас, ми погоджуємося $з$ думкою вчених, які пов'язують управління конкурентоспроможністю з фрунціями управління, серед яких традиційно виді- 
ляють планування, організацію, координацію, контроль, та мотивацію.

Ми вважаємо, що специфіка управління конкурентоспроможністю туристичних підприємств в сучасних умовах буде полягати в необхідності забезпечення підвищеної гнучкості у пропозиціях туристичного продукту, у можливостях швидкої трансорормації навіть вже реалізованих туристичних продуктів, та адаптації їх до умов зовнішнього середовища, що постійно змінюються, у гнучкості роботи із споживачами в умовах нестабільності ринку туристичних послуг. Все це вимагає значного пришвидшення прийняття управлінських рішень, та розширення можливостей делегування повноважень щодо прийняття окремих управлінських рішень менеджерам нижчої ланки, для забезпечення швидкості реакцій.

Виходячи з вищезазначеного, вважаємо за потрібне визначити наступні принципи управління конкурентоспроможністю туристичного підприємства в умовах нестабільності:

- гнучкість в прийнятті управлінських рішень;

- швидкість реакцій на зміни в зовнішньому середовищі;

- оперативної інформованості щодо змін у зовнішньому середовищі.

Дотримання цих принципів можливе тільки за умови постійного моніторингу змін у зовнішньому середовищі, тому, не зважаючи на те, що сам по собі моніторинг є складовою організаційного забезпечення, вважаємо за необхідне відокремити його. Також, на нашу думку В процесі управління конкурентоспроможністю туристичного підприємства обов'язково необхідно в першу чергу сконцентруватись на визначенні задач, які має вирішувати побудова системи управління конкурентоспроможністю. Такі задачі можуть змінюватися 3 плином часу, у відповідь на зміни в зовнішньому середовищі організації, та зміну внутрішніх цілей (рис. 5).

На рисунку показано взаємозв'язок внутрішньої поведінки в організації та змінами в зовнішньому середовищі. Нашою метою було показати необхідність постійного моніторингу, та швидкої реакції на виявлені зміни. Останнім часом, в умовах пандемії, саме швидкість реагування, на нашу домку є запорукою збереження конкурентоспроможності, та фрормування потенціалу конкурентоспроможності туристичного підприємства.

Коли ми кажемо про оперативну зміну плану, ми маємо на увазі внесення коректувань у вже існуючий план, що дозволить в результаті компанії наблизитись до заплано- ваних показників продажу туристичного продукту у кількісному та грошовому вимірі, а також наблизитися до запланованих показників ефективності діяльності компанії.

Водночас, події останніх років показують, що іноді плани потрібно змінювати кардинально, тому що за умов глобальних обмежень, перед багатьма туристичними підприємствами, на перший план вийшла задача виживання. В таких умовах забезпечення есрективності вже відходить на другий план, поступаючись місцем необхідності збереження життєздатності організації, робочих місць, мінімізації збитків.

Коли ми кажемо про оперативну зміну плану, ми маємо на увазі внесення коректувань у вже існуючий план, що дозволить в результаті компанії наблизитись до запланованих показників продажу туристичного продукту у кількісному та грошовому вимірі, а також наблизитися до запланованих показників ефективності діяльності компанії. Водночас, події останніх років показують, що іноді плани потрібно змінювати кардинально, тому що за умов глобальних обмежень, перед багатьма туристичними підприємствами, на перший план вийшла задача виживання. В таких умовах забезпечення есрективності вже відходить на другий план, поступаючись місцем необхідності збереження життєздатності організації, робочих місць, мінімізації збитків.

Коли ми кажемо про оперативні організаційні зміни, то маємо на увазі необхідність менеджменту компанії бути готовими, до швидких змін в організації деяких процесів. Наприклад, делегування частини повноважень щодо прийняття управлінських рішень менеджерам більш низької ланки, задля забезпечення можливості пришвидшення швидкості реакцій. Також, це готовність до швидкого перерозподілу обов'язків персоналу всіх рівнів.

Коли ми кажемо про оперативні зміни в координації діяльності туристичного підприємства, то це означає готовність до швидкої зміни взаємозв'язків між відділами компанії задля пришвидшення реагування на зовнішні зміни. Персонал компанії має бути готовим до роботи в умовах постійних змін, та необхідності швидкого реагування.

Коли ми кажемо про оперативні зміни в системі мотивації, то маємо на увазі, що в період нестабільності ми маємо проявляти баланс між збереженням робочих місць, та рівнем заробітної плати. Проте, в умовах фрінансової нестабільності підприємства, коли 
Управління конкурентоспроможністю туристичного підприємства в умовах нестабільності та постійних змін

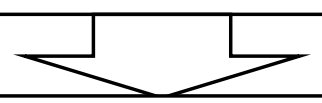

Задачі системи управління конкурентоспроможністю туристичного підприємства в умовах нестабільності, та постійних змін:

- забезпечення підвищеної гнучкості у пропозиціях туристичного продукту;

- забезпечення можливостях швидкої трансформації навіть вже реалізованих туристичних продуктів, та адаптації їх до викликів зовнішнього середовища, що постійно змінюється;

- забезпечення гнучкості роботи із споживачами в умовах нестабільності ринку туристичних послуг;

- забезпечення швидкості прийняття управлінських рішень;

- забезпечення швидкості реагування всієї системи управління на зміну в управлінських рішеннях;

- забезпечення швидкості реакцій всього персоналу туристичної компанії, задіяного в створенні, реалізації і супровідного обслуговування туристичного продукту

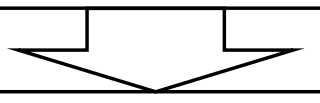

Виявлення зовнішніх та внутрішніх складових конкурентоспроможності конкретного туристичного підприємства

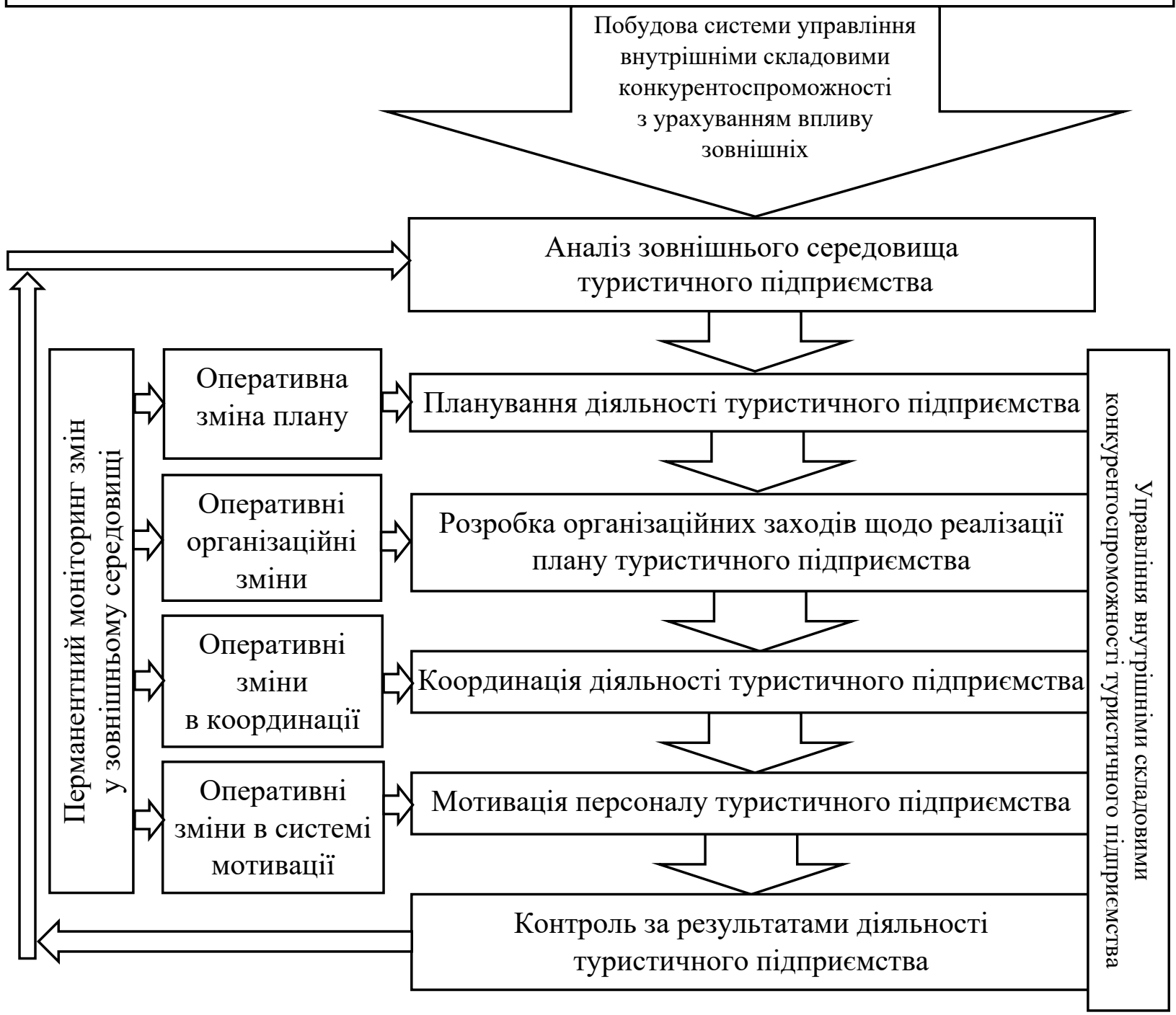

Рис. 5. Процес управління конкурентоспроможністю туристичного підприємства в умовах нестабільності 
збереження рівня матеріального стимулювання стає неможливим, найважливішу роль починає відігравати своєчасне оперативне та гнучке нефінансове мотивування.

Здійснення періодичного контролю за результатами діяльності туристичного підприємства необхідне для того, щоб проана- лізувати відповідність отриманих результатів раніше затвердженим планам, та створити базис для подальшого планування розвитку i фрункціонування компанії, створити орієнтири для подальшої роботи над збереженням та збільшенням конкурентоспроможності туристичної компанії.

\section{СПИСОК ВИКОРИСТАНИХ ДЖЕРЕЛ:}

1. Кадирус І.Г. Конкурентоспроможність підприємства та фактори, що на неї впливають. Ефективна економіка. 2014. № 5. URL: http://www.economy.nayka.com.ua/?op=1\&z=3390 (дата звернення: 30.11.2021).

2. Підлужна О.Б., Колос З.В. Конкурентоспроможність в туризмі як провідний напрям сталого розвитку. Вісник ХНАУ ім. В.В. Докучаєва. Серія «Економічні науки». 2019. № 1. С. 469-477. URL: https://visen.knau.kharkov.ua/20191_45.html (дата звернення: 30.11.2021).

3. Мануйлович Ю.М. Дослідження сутності та трактування поняття конкурентоспроможності підприємства. Маркетинг і менеджмент інновацій. 2013. № 4. URL: http://nbuv.gov.ua/UJRN/Mimi_2013_4_28 (дата звернення: 30.11.2021).

4. Лужанська Т.Ю., Костенко С.А., Катц Е.Б., Будкевич Г.Б. Оцінка та напрямки удосконалення конкурентоспроможності туристичних підприємств. Економічний фрорум. 2015. № 4. C. 258-267. URL: https://tourlib.net/ statti_ukr/luzhanska.htm (дата звернення: 30.11.2021).

5. Солов'янчик А.В. Аналіз чинників, що впливають на рівень конкурентоспроможності підприємств ринку туристичних послуг. Науковий вісник Ужгородського національного університету. 2015. Випуск 5. C. 130-133. URL: http://www.visnyk-econom.uzhnu.uz.ua/archive/5_2015ua/30.pdf (дата звернення: 29.12.2021).

6. Кравченко О.М., Кула М.В. Левицький Д.В. Управління конкурентоспроможністю підприємства в умовах здійснення зовнішньоекономічної діяльності. Економіка. Фінанси. Право. 2021. № 2. С. 13-17. URL: http://efp.in.ua/uk/journal-article/598

7. COVID-19 and tourism. 2020: A year in review. UNWTO. January 2021. URL: https://webunwto.s3.eu-west1.amazonaws.com/s3fs-public/2020-12/2020_Year_in_Review_0.pdf (дата звернення: 30.11.2021).

8. Global tourism sees upturn in Q3 but recovery remains fragile. UNWTO. November 2021. URL: https://www.unwto.org/taxonomy/term/347 (дата звернення: 30.11.2021).

9. Статистичний щорічник України 2020. Державна служба статистики України. 2021. 455 с. URL: http://ukrstat.gov.ua/druk/publicat/kat_u/2021/zb/11/Yearbook_2020.

10. Статистичний щорічник України 2016. Державна служба статистики України. 2017. 611 с. URL: http://ukrstat.gov.ua/druk/publicat/Arhiv_u/01/Arch_zor_zb.htm

11. Яценко М.С., Беспала О.А., Ференець Я.В. Система контролю та менеджменту якості продукції, як сучасний метод управлінського контролю на підприємстві. Економіка. Фінанси. Право. 2017. № 6. C. 44-46. URL: http://www.irbis-nbuv.gov.ua/cgi-bin/irbis_nbuv/cgiirbis_64.exe?I21DBN=LINK\&P21DBN=UJR $N \& Z 21 \mid D=\& S 21 R E F=10 \& S 21 C N R=20 \& S 21 S T N=1 \& S 21 F M T=A S P \_m e t a \& C 21 C O M=S \& 2 \_S 21 P 03=F I L A=\& 2$ S21STR=ecfipr_2017_6(2)__13

12. Храпкіна В.В. Управління конкурентоспроможністю підприємств. Причорноморські економічні студії. 2020. Випуск 51. С. 245-248. URL: http://bses.in.ua/journals/2020/51_2020/41.pdf (дата звернення: 27.11.2021).

13. Солов'янчик А.В. Стратегічне управління конкурентоспроможністю підприємства ринку послуг. Управління розвитком. 2005. № 4(182). С. 48-54.

14. Гавриш О.А. Принципи управління рівнем конкурентоспроможності підприємств. Ефрективна економіка. 2013. № 10. URL: http://www.economy.nayka.com.ua/?op=1\&z=1774 (дата звернення: 27.11.2021).

15. Діденко О.Є., Жураківський П.І. Модель управління конкурентоспроможністю підприємства. Ефективна економіка. 2017. № 5. URL: http://www.economy.nayka.com.ua/?op=1\&z=5590 (дата звернення: 27.11.2021).

16. Драган О.І. Управління конкурентоспроможністю підприємств (теоретичні аспекти) : монограсрія. Київ : ДАКККіМ, 2006. 160 c.

\section{REFERENCES:}

1. Kadyrus I.H. (2014) Konkurentospromozhnist' pidpryyemstva ta faktory, shcho na neyi vplyvayut' [Competitiveness of the enterprise and the factors that affect it]. Efektyvna ekonomika, no. 5. Available at: http://www.economy.nayka.com.ua/?op=1\&z=3390 (accessed 30 November 2021). 
2. Pidluzhna O.B., Kolos Z.V. (2019) Konkurentospromozhnist' v turyzmi yak providnyy napryam staloho rozvytku [Competitiveness in tourism as a leading area of sustainable developmen.]. Visnyk KHNAU im. V.V. Dokuchayeva. Seriya «Ekonomichni nauky», no. 1, pp. 469-477. Available at: https://visen.knau.kharkov.ua/20191_45.html (accessed 30 November 2021).

3. Manuylovych Yu.M. (2013) Doslidzhennya sutnosti ta traktuvannya ponyattya konkurentospromozhnosti pidpryyemstva [Research of the essence and interpretation of the concept of enterprise competitiveness]. Marketynh $i$ menedzhment innovatsiy, no. 4. Available at: http://nbuv.gov.ua/UJRN/Mimi_2013_4_28 (accessed 30 November 2021).

4. Luzhans'ka T.Yu., Kostenko S.A., Katts E.B., Budkevych H.B. (2015) Otsinka ta napryamky udoskonalennya konkurentospromozhnosti turystychnykh pidpryyemstv [Assessment and directions of improving the competitiveness of tourism enterprises]. Ekonomichnyy forum, no. 4, pp. 258-267. Available at: https://tourlib.net/statti_ukr/ luzhanska.htm (accessed 30 November 2021).

5. Solov"yanchyk A.V. (2015) Analiz chynnykiv, shcho vplyvayut' na riven' konkurentospromozhnosti pidpryyemstv rynku turystychnykh posluh [Analysis of factors influencing the level of competitiveness of enterprises in the market of tourist services]. Naukovyy visnyk Uzhhorods'koho natsional'noho universytetu, vol. 5, pp. 130-133. Available at: http://www.visnyk-econom.uzhnu.uz.ua/archive/5_2015ua/30.pdf

6. Kravchenko O.M., Kula M.V. Levyts'kyy D.V. (2021) Upravlinnya konkurentospromozhnistyu pidpryyemstva $\checkmark$ umovakh zdiysnennya zovnishn'oekonomichnoyi diyal'nosti [Managing the competitiveness of the enterprise in terms of foreign economic activity]. Ekonomika. Finansy. Pravo, no. 2/1, pp. 13-17. Available at: http://efp.in.ua/uk/ journal-article/598

7. COVID-19 and tourism. 2020: A year in review. UNWTO. January 2021. Available at: https://webunwto.s3. eu-west-1.amazonaws.com/s3fs-public/2020-12/2020_Year_in_Review_0.pdf (accessed 30 November 2021).

8. Global tourism sees upturn in Q3 but recovery remains fragile. UNWTO. November 2021. Available at: https://www.unwto.org/taxonomy/term/347 (accessed 30 November 2021).

9. Statystychnyy shchorichnyk Ukrayiny 2020 [Statistical Yearbook of Ukraine 2020]. Derzhavna sluzhba statystyky Ukrayiny. 2021 r. 455 p. Available at: http://ukrstat.gov.ua/druk/publicat/kat_u/2021/zb/11/Yearbook_2020.pdf

10. Statystychnyy shchorichnyk Ukrayiny 2016 [Statistical Yearbook of Ukraine 2016]. Derzhavna sluzhba statystyky Ukrayiny. 2017 r. 611 p. Available at: http://ukrstat.gov.ua/druk/publicat/Arhiv_u/01/Arch_zor_zb.htm

11. Yatsenko M.S., Bespala O.A., Ferenets' YA.V. (2017) Systema kontrolyu ta menedzhmentu yakosti produktsiyi, yak suchasnyy metod upravlins'koho kontrolyu na pidpryyemstvi [Product quality control and management system as a modern method of management control at the enterprise]. Ekonomika. Finansy. Pravo, no. 6/2, pp. 44-46. Available at: http://www.irbis-nbuv.gov.ua/cgi-bin/irbis_nbuv/cgiirbis_64.exe?/21DBN=LINK\&P21DBN=UJRN\&Z21 $I D=\& S 21 R E F=10 \& S 21 C N R=20 \& S 21 S T N=1 \& S 21 F M T=A S P \_m e t a \& C 21 C O M=S \& 2 \_S 21 P 03=F I L A=\& 2 \_S 21 S T R=$ ecfipr_2017_6(2)_13

12. Khrapkina V.V. (2020) Upravlinnya konkurentospromozhnistyu pidpryyemstv [Enterprise competitiveness management]. Prychornomors'ki ekonomichni studiyi, vol. 51, pp. 245-248. Available at: http://bses.in.ua/journals/ 2020/51_2020/41.pdf (accessed 27 November 2021).

13. Solov"yanchyk A.V. (2005) Stratehichne upravlinnya konkurentospromozhnistyu pidpryyemstva rynku posluh [Strategic management of the competitiveness of the service market]. Upravlinnya rozvytkom, no. 4(182), pp. 48-54.

14. Havrysh O.A. (2013) Pryntsypy upravlinnya rivnem konkurentospromozhnosti pidpryyemstv [Principles of managing the level of competitiveness of enterprises]. Efektyvna ekonomika, no. 10. Available at: http://www.economy.nayka.com.ua/?op=1\&z=1774 (accessed 27 November 2021).

15. Didenko O.Ye., Zhurakivs'kyy P.I. (2017) Model' upravlinnya konkurentospromozhnistyu pidpryyemstva [Enterprise competitiveness management model]. Efektyvna ekonomika, no. 5. Available at: http://www.economy.nayka.com.ua/?op=1\&z=5590 (accessed 27 November 2021).

16. Drahan O.I. (2006) Upravlinnya konkurentospromozhnistyu pidpryyemstv [Management of enterprise competitiveness (theoretical aspects)] (teoretychni aspekty): monohrafiya. Kyiv: DAKKKiM, 160 p. (in Ukrainian) 